\title{
The Europeanization of Balkans-yes or no
}

\author{
Liljana Siljanovska \\ South East European University-Tetovo, Republic of Macedonia
}

Email address:

siljanovska@seeu.edu.mk, siljanovska2002@yahoo.com

\section{To cite this article:}

Liljana Siljanovska. The Europeanization of Balkans-Yes or No. Social Sciences. Vol. 2, No. 3, 2013, pp. 105-111.

doi: $10.11648 /$ j.ss.20130203.12

\begin{abstract}
Should the Balkan be place where the credibility of European Union will happen? This question is becoming increasingly evident after the rejection of the EU constitution by France and the Netherlands in the middle of 2005 which is mostly resulted by dissatisfaction of voters of the internal political governing in their countries. This conclusion was further created by created mediumistic reality for Euro integrated processes of the aspirant and candidate countries for their membership through one longer period of creation of public opinion (mostly intensive from 2003-2005). What have mediumistic forecasts show for the Europeanization of the Balkans? Controversy about the expansion of the Union have been treated by a media content that the international and domestic public channelled the European public opinion through several dimensions of influence. First, on the local mediumistic scene, the European public opinion, is firstly manifested more as an ideology, less as a rational strategic preference for the creation of European values through reforms in all segments of social-political, economic and cultural life. In those frames, the media have created a framework for the creation of collective memory of Euro integrations, Euro-consciousness to integrate in the normative collective , economic, social and institutional system whose cultured common denominator are the new social relationships, and politics of influences between EU and countries out of EU The concept of integration and inclusion is idealized to the extent which ii itself negates the concept of exclusion and marginalization. All this is in contradiction with some postmodern theories that suggest some of the possible changes of transitional societies. Here could be included destruction, that is the collapse of old institutions and especially the actual questions regarding the process of fragmentation of the society to micro-social units, that is, to small parallel worlds and their adjustment. Atomization of societies, which would result as possibility of conflicting new changes, would lose the social dimension, and in the enter of attention are individuals that with their free rational mind will be faced with a wild-takings power.
\end{abstract}

Keywords: Europeanization, Media Reality, Balkanization, European Values, West-Balkan Countries

\section{Introduction}

Should the Balkan be place where the credibility of European Union will happen? This question is becoming increasingly evident after the rejection of the EU constitution by France and the Netherlands in the middle of 2005 which is mostly resulted by dissatisfaction of voters of the internal political governing in their countries. This conclusion was further created by created mediumistic reality for Euro integrated processes of the aspirant and candidate countries for their membership through one longer period of creation of public opinion (mostly intensive from 2003-2005).

What have mediumistic forecasts show for the Europeanization of the Balkans? Controversy about the expansion of the Union have been treated by a media content that the international and domestic public channeled the European public opinion through several dimensions of influence. First, on the local mediumistic scene, the European public opinion, is firstly manifested more as an ideology, less as a rational strategic preference for the creation of European values through reforms in all segments of social-political, economic and cultural life. In those frames, the media have created a framework for the creation of collective memory of Euro integrations, Euroconsciousness to integrate in the normative collective, economic, social and institutional system whose cultured common denominator are the new social relationships, relationships . and politics of influences between EU and countries out of EU The concept of integration and inclusion is idealized to the extent which ii itself negates the concept of exclusion and marginalization. All this is in contradiction with some postmodern theories that suggest some of the possible changes of transitional societies. Here 
could be included destruction, that is the collapse of old institutions and especially the actual questions regarding the process of fragmentation of the society to micro-social units, that is, to small parallel worlds and their adjustment. Atomization of societies, which would result as possibility of conflicting new changes, would lose the social dimension, and in the center of attention are individuals that with their free rational mind will be faced with a wildtakings power.

\section{Mediumistic Reality of Europeanization of the Balkans after 2005}

European public lives all this as pragmatic provocation of agenda for the future EU. Analysis shows that the expansion of the campaign mediumistic phraseology of Europeanization of the Balkans divided also the global community through different viewpoints placed in the influencing European and American media. Their theoretical generalization sets two conceptually different theses. One says that the Balkans should be the place where the European Union should justify that transforming power could function applying new values, politics and regulative in regions where the countries are weak, and the societies divided. Second theses says that the West-Balkans countries would be second-degree in the European agenda because of the new constellation of relationships in the other regions especially in Near East, crises of political systems in Arabian countries, but also because of institutional and structural and economic, financial debt crisis within the European Union.

\section{For Different Viewpoints in European and American}

Renowned Economist newspaper of London back in 2006 , by several analyzes of the process of further enlargement of the European Union criticized the relationship of large countries toward the Balkan. It is especially important the preventing that statements of some European politicians could encourage the local nationalism and reduce the interest of the region to join the Europe.

"European Commission are nervous about the Balkans which is facing its six critical months in which determine the future of Serbia, Monte Negro and Kosovo, and the pro-European government in the region are under strong press of nationalists permanently talking that the Union may be will never fulfill the promises."'(1)

The Magazine reveals that it is not accurate evaluations of French politicians, that the resistance to accept new members is the result of the failure of the referendum on the European Constitution in France and the Netherlands. According Economist, a French analyze shows that only 3\% of those voting in France against the Constitution of EU, did it because they were against the expansion of EU.

Under the title "Some Balkan countries would be able to hit upon close doors in European Union in the same analyzed period ( it means since 2006)"Financial Times writes that the path toward the Union is secured for Romania. Bulgaria and Croatia, but there are serious threat for the European future of Macedonia, Albania, Serbia, Monte Negro and Bosnia \& Herzegovina.

"Although the four countries of West Balkans have together about 25 million inhabitants, which is a little bit more than a half of the general population of Poland, the leaders of the countries, such as Germany and France, loudly ask if the European Union has already become great enough". (2)

Analyzes also show that according mediums impressions, Europe's attention didn't succeed to attract the outburst of violence of Kosovo in March 2004. The riots are trivialized and defocused by the European Union. After the social circumstances happening at that period in the actual and medium reality influenced are also other international regions where nations are built, such as Iraq and Afghanistan. At that period Balks seemed to be successful story which should be building, but without European will to treat it.

Researching in analyzed period 2003-2006 indicate that the region in which Republic of Macedonia belongs do not build the European profile of countries. Contrary to this, there is mix of weak countries and international protectorates in which Europe has stationed almost half of its usable capacities. What is important for EU is socialeconomic reality of Balkan countries. Their economic development is very low or doesn't exist at all. There is high unemployment, about $40 \%$ and the most existing problem is corruption . The law democracy of governmental institutions causes the law confidence of population in achieving their rights in the frame of existing regulations and practicing of national institutions. Parallel with internationalization of criminal networks, the criminalization of politics takes place on the Balkans.

\section{Europeanization of West-Balkan Countries}

The opinion of European Commission for Rep. of Macedonia in September 2005 was enough over the zero for the Council of ministers of EU, so that, in December the candidate status was granted. Scanning of socioeconomic and political condition in the country, the data about the human development in the worlds, conflicts of valuable systems, indicates that this high level in relationships with EU is not resulted by the practical conducting of real reforms, but it is in fact the political will in context of socio-political, economic and cultural reality in Balkans surrounding. Polarization of Europe towards Macedonia, is mainly visible in two things.

In the foreground, in front of all, is the Ohrid Agreement 
resulted of arm conflict in 2001, that makes Macedonia a model that EU needs. Multinational concept of social management that EU implemented in Macedonia, could be applied for solving some other Balkans questions in future. The second merit that Macedonia gets the candidate status is the hard regional context. In the years before and after 2005 were lasting negotiations for future status of, now, independent country Kosovo. Then, in the common country Serbia and Monte Negro, there is political uncertainty, and in Albania, there is not clear political path that Albanian government will follow. All this feared Europe, because in all these events, it will not secure more secured place of Macedonian case, the general politics of EU towards the Balkans could get in danger. Politicization of Europe towards Macedonian membership in European family comes in moments when Brussels couldn't commend with great success in internal or external politics, since its consolidation was torn apart in the politicization of vital institutional reform by the great European members: Great Britain, Germany, France, Holland and their skepticism toward expanding at the expense of national comfort in realization of politic of its own countries.

European Union recognizes declarative politics led by Republic of Macedonia, since according the statements given by European diplomats dealing with euro integrations of the country, the European mission is completed when the rules and European regulative are respected, when the reality of the region is changed and the long-term reforms, such as decentralization and equal presence of Ohrid agreement as one of the essential changes with the agreement, will be truly applied. The fight against corruption is also on the top of the priorities of the Union, because this phenomenon destroys the society and unable its development. To talks about one, and to do another, is situation often used by Balkans leaders in their debates with Europe, which is well known to EU.

The medium qualification that the candidate status granted to Macedonia in 2005 is greatly important for whole Balkans, and also for the process of further expanding of EU, has been dimensioned because of two reasons. First, it is questioned, how much do the Union's promises cost, especially that granted to Balkans countries in 2003 in Thessaloniki. Secondly it is questioned the legitimacy of European commission, the main factor on process of expanding. If the European council didn't accept the suggestion of the Commission for Macedonia to become country candidate, then the same commission would be devaluated, because it could have long lasting consequences, at the moment when the legitimacy of the Union was not so strong and especially when the financial agreement of the Union was accepted. Because of that the decision for Rep. of Macedonia at the time had great importance.

Mediumistic analyzes in 2006 indicate the statement that R. of Macedonia has the possibility to contribute the acceleration of general process of integration of the Balkans in the European Union. For the analysts , 2006 was key year for the region. Has the Balkans solved all inherited problems and how is the ending process of Balkanization of south-eastern countries going on?

In Bosnia and Herzegovina, there was no any constitutional agreement. Few years later, in this 2012, the pessimism is increasing of the analyzes of social reality in this Balkan country and more because of the politicians acts in three spheres of influence. Latest prediction of former high international representative in Bosnia and Herzegovina, Pedi Eshdown (3) says that this country goes to destruction because of the acts of the Republic Srpska from one side, and Bosniak Parties, on the other side , which work more in strengthening of the federation, and on the third side, Croatians strengthen the idea of third entity. In such constellation of relationships, European Union should strengthen the support for building strong central governmental institutions. Dissolution toward Bosnia and Herzegovina approaches as a result of political governing of Republic Srpska, has a plan to make the country completely dysfunctional, so that be waived of it, that of course, will resulted same affect by other sides. Separatist acts should not renew the conflicts in Bosnia and Herzegovina, but will hinder democratic development of institutional capacities, so instead on consolidation of the country, even the Bosniak parties have greater attention to Federation more than to the state. Which will be the political role of European Union? It should be more determined and to encourage powers seeking to stent then state of Bosnia and Herzegovina. Also, base on the established practice of previous economic and political crisis, the political pressure as instrument for euro integration is expecting to be directed towards Republic of Serbia , and to condition the Serbian path toward the Union.

The political role toward Serbia has been played by EU with serial diplomatic pressures, coordinated with American diplomacy, for improving the relationships and undertake concrete activities for cooperation on the relation Belgrade-Prishtina. It resulted with getting candidate status of Serbia for member of EU in March this year. As it seems, the political decision of the Union that will result with concrete measures in liberalization of restrictive Serbian politics before dissociation of the activities taken by the Serbian minority in Northern Kosovo, establishing good neighborly politics with newfound state, establishing good neighborly relations with other Balkan countries in the region, as well as the democratization of political relations, strengthening of the law and economy inside the state of Serbia. In fact, distancing of the Serbian politics of the referendum of the Serbians on Kosovo has shown the Serbian determination for euro Atlantic integration, as political, economic and collective secured decision. 


\section{Balkans as Main Coordinator of Drug Trafficking}

The most recent analyzes of UN and experts against drug smuggling, confirm that from Afghanistan via Turkey and Balkans corridors, arrives most quantity of drug to the West European countries . It is even $80 \%$ of the drug. Although the countries of the region recently cooperate mostly in the fight against drugs smuggling, not all possibilities have been used. It means wider cooperation on global plan. The accent should be pointed to the local criminal groups often cooperated also by the people in diaspora. Especially, on the Balkans, among the local groups the most famous is Albanian mafia, which is specialized in heroin smuggling in the region and in EU countries. In that net connected are also Italian Drageta, Montenegrin drug clans, Turkish drug-cartels, as well as Russian and Caucasus criminals. In smuggling participate Turkish Curds connected with members of that people residing in Iraq, Iran and central Asia. They have welldeveloped smuggling channels from Afghanistan which is the greatest producer of heroin in the world.

\section{Conflicts of Value Systems in West-Balkans Countries}

In the period 1990 , the countries of Wets Balkans belonged to socialistic block and after the raise of iron curtain from close societies where the foreign influence was almost impossible, these countries faced with the process of globalization, that resulted fast changes in values of post socialist countries established as period of transition.

The social-cultural ambient of West-Balkans countries inevitably affects the changes of value systems from one side, and on the other side, the permanent models of value established in national and cultural identities, and among them also in Macedonia, shows tendencies of resistance to changes. Social context of forming new values to the path to euro integration processes of economic plan faces with dysfunctional market economy, slow and non-transparent privatization, with economic capacities accompanied with bureaucratized administrative processes being traditional with socialist system of management and with high level of bribery, corruption and economic crime. Analyze of economic situation in the West Balkans countries shows low level of gross domestic product which is result of low level of direct foreign investment and bad management of domestic production capacities accompanied with nonstandardization of quality, assortment and ranking of Balkans products according rules and standards of international market. All this contributes to unemployment, poverty, large class differences and reduced social mobility.

The democratization of political governing with establishing of multi parties and pluralism of interests, functioning of parliamentary democracy and forming and activity of political parties, citizen associations and introduction of functioning rules of legal country, are new values in period of transition of political surrounding of West Balkans Countries. They are based on universal principles for democratic rights and freedoms, right of free expression of citizens, democratic forms of political decision and governing of law in system institutions. It must be noted that these phenomena, in fact, are in practice more idealized than performed. As a result of that, Macedonia, Serbia, Kosovo, Monte Negro and Bosnia and Herzegovina face with insufficiently implemented forms, means and modalities of practicing the proclaimed European values in development of political system of deciding and governing with institutions in implementation of legislative, court and executive power.

Conflicts of value systems in these Balkans countries appear because of non-complimentary between the new democratic-liberal and traditional centralized values. In development of social-political relations in the Balkans countries the conflict of value systems is expressed through issue of nondemocratic forms of governing of the law, politicization of all objects of social life, bribery, corruption, protection of personal and party interests instead the interests of the citizens, that is, the voters, through distrust towards institutions of the systems, issue of conflict situations, violence and insecurity of the citizens.

Economic, political and cultural dubious in social processes and changes of West-Balkan countries in forming the post communist values in transition period, have been reflected on the social sphere. They have been introduced without existing of concrete strategy for functioning of social politics and absence of mechanisms of social care and protection of citizens. Evident is inefficacy of administration, absence of criteria of value, and the conflict of interests is characteristic of general social system of the countries of West Balkans. Absence of changes that will build as social countries, result with increase social uncertainly and dissatisfaction of population especially by adult and young population.

In the field of culture, positive and negative trends are formed of many processes and issues such as falling of moral values, illicit rate of politicization of cultural activities, idealization, increase of ethno centrism in culture, negative influence of religious tenses as well as lack of essential criteria in accepting some of global civilization value. Also in Macedonia, as part of WestBalkan countries during the last years its significant the establishment and development of modern trends in education and science, but in absence of clear criteria of possibilities and justification of their application. Also the high attainments in the sphere of artistic creation are insufficiently stimulated and are not properly presented to the domestic and foreign public, and the developing processes in protection and presentation of cultural inheritance are burdened with financial, organizational and ideological problems.

In forming new value systems of West-Balkans countries, 
great influence has also the development of media systems. Analyzes of media space shows inconsistency, contradictory and ambiguity in realization of media functions. From one side there is developed net of media, and on the side, more media are with problematic quality in presenting program content, lack of developed own production, sensationalism is cherished, uncritical exposure of popular culture and so called civil values.

\section{Where is Macedonia Going}

On the referendum 20 years ago, Macedonia population, with almost $98 \%$, determined their wish for their own and independent country after the break of Yugoslavia. Politics and society were and still are united regarding the main target: membership in NATO and EU. But, but soon found that the road will be long and patchy.

The recognition by western countries was delayed through many years, although of them established an arbitration commission of legal experts (Badenter Commission, so called according the Frenchman Robert Badenter, who chairs with it) in the beginning of 1992 determined that only Slovenia and Macedonia of the Former Yugoslav Republic satisfied all conditions for international recognition as independent countries. Soon after that, Germany recognized Slovenia and Croatia, and even after four years Macedonia was recognized. But, it is fact that Macedonia did not set out immediately decisive in direction of independence, but first, together with Bosnia and Herzegovina, tried to save some form of Yugoslav federation which was destroying. ( so called "Plan Gligorov-Izetbegovic, both presidents of those countries).

Macedonia until April 1993 was admitted to the UN, but with provisory sign "Former Yugoslav Republic of Macedonia" (FYROM) because Greece countered the use of the official name Republic of Macedonia.

Macedonia had to fight with economic consequences because of the wars in other parts of Former Yugoslavia and two embargos - international against Serbia and unilaterally, against the Greek trade embargo.

During the war in Kosovo 1999 the poor country temporary accommodated 300 refugees . In 2001 Macedonia found itself on the brink of civil war.

In 2005 Macedonia got the status of official candidate for EU membership, but also further, almost 7 years, it waits the beginning of accession negotiations. In 2008 members of NATO determined that Macedonia satisfied all conditions for membership, but beside that, but because of the Greek veto, Macedonia is still waiting in front of the doors of Alliance.

Two problems are withdrawn through 20 years independent Macedonia: dispute with Greece regarding the name and relations between nationals. Second question Macedonia decides better than the other countries of the region. With Ohrid Frame Agreement, made with Western pressure, not only the conflict between state security forces and risen Albanians was stopped, but also it was made base for cohabit of all ethnic groups of multinational country. The general position of Macedonian Albanians is significantly improved. They are parity represented in governmental and social institutions. Some of the Albanian party is always partner with Macedonian party being in power. Albanian as official language is spoken also during the sessions of the Council (Macedonian parliament). Albanian flag is legally used beside Macedonian one. The relationships among nationals in the country are not idyllic, but are completely acceptable, with potential of further improvement.

Curiosity is, and unique example in international relationships, one country to deny the right to another country to name itself as it likes. In the world it is not rarity the provinces and regions in various countries to have same names. Only Greece minds that the country of Macedonia has the same name as its northern province. Macedonia has been recognized under its official name by 133 countries (among them USA, Russia, and China, members of Council of Security of the UN, then India, Canada, etc), another 30 countries in bilateral communication uses the name Republic of Macedonia. Mediation of UN doesn't bring any decision regarding this dispute.

Greece argumentation that it afraid of possible territorial claims of the small and economic weak Macedonia, with only several thousand soldiers and to some extent dependent of Greek capital, doesn't sound plausible. Besides that, Macedonia in the constitution inserts that it hasn't any territorial claims towards any neighbor. Finally, Greece does not bother the fact that almost five decades before its independency, Macedonia was existing as republic in Yugoslav federation.

Greece using or abusing the consensual principle of deciding in EU and NATO with veto had blocked Euro Atlantic integration of Macedonia, although with bilateral Temporal agreement of 1995 had obliged itself not to prevent the admission under the name FYROM. Because of that Macedonia applies to the International Court of Justice. It is open question if only the name is disputed for Greece, as it says, or it want to negate the identity and language of Macedonians, as they assumed. It is question what does Macedonia want to achieve with antiquization . Until now, in any case, it has gather only critics.

German Bundestag with declaration as of 2004 recommended usage of Constitutional name of Macedonia. The Government firmly stands o EU line. "We are connected to the EU politics according the region and have no occasion of own activities and independent performance. We practically couldn't do anything un until the problem with the name is solved", states for Deutsche Welle in 2009 Gernot Erler, at that time, state secretary in the German ministry of foreign affairs. (4)

20th - anniversary of independence and 10th anniversary of signing the Frame agreement which terminates the most serious conflict that shook the country, are sufficient to be said that Macedonia leaves significant year behind itself. Year of opening many discussions of 
direction, targets and forms of realization, of the future political governing, of internal relationships, among internal powers and relations out, with international centers of power. Year of early re-elections, new coalition between old partners in VMRO-DPMNE and DUI, facing of the Macedonian opposition with the fact that there are no capacities to be adequate counterweight to the policies that govern.

In such conditions, it becomes unreal to expect that in 2012 the two-decades dispute will terminate. The Judgment of Haag, which is great victory of Macedonia, in which it is clearly précised that Greece is guilty and in Bucharest 2008 breached the Temporary agreement, hardly to make some changes. This legal and moral satisfaction of Macedonia will be base for the strategy of its diplomacy in 2012. Insistence to respect the decision and conviction of countries-members not to close eyes in front of the sound of justice will be basis of foreign-political activities. Will Macedonia be mentioned in NATO in Chicago, Whether Greece would dare to block again, if the judgment will really change something?

\section{Balkanization of Human Rights in Europe}

Analyzes of the report of international organization located in USA, Human Rites Vogue (5) indicate to getting worse of human rights. European practice indicates that this is result of four European tendencies. First, limited civil freedom in countries with anti terroristic measurements. Then, debates being tumultuous regarding the minority and immigrants in Europe. Third tendency of great importance is increasing influence of populist and extremist parties in politics, reduced efficacy of traditional institutions for protection of human rights. Especially alarming is the situation in Hungary, Romania, Bulgaria, Check Republic and Slovakia. In these countries members of the Union, significant are violence attacks and anti-Romani rhetoric, it is found insignificant progress in preventing destroy of their residences, and often presence of segregation of Romani at schools. All this is happening against the decisions of European court of human rights and against hundreds millions Euros of EU funds flowing in these countries.

Regarding the situation with human rights in Kosovo, in 2011 it could be remarks little bit improving, but also presence of marginalization and discrimination of minorities. According the analyze of Human Rites vogue, Kosovo Romani, Ashcali and Egyptians are still marginalized and discriminated since there is great rate of unemployment, leaving the schools and great rate of mortality. Also there are incidents among nationals, especially among Kosovo Albanians and Serbs in North Kosovo. Although last year 60 were registered ,there were serious attacks and killings. Especially the visa liberalization of Serbia, economic difficulties and discrimination of minorities in Kosovo, Serbia and Kosovo ,during the last previous years, has given greatest number of applicants for asylum in industrialized countries. Deported Kosovo citizens from Western Europe reside in informal settlements without water and lighting. Because of afraid for their security, German province North Reina Westville terminates the arriving of the applicants back in Kosovo.

\section{Conclusion}

European debt crises according many prominent advocates of economic politic couldn't be solved with "tightening the belt". They claim that the expansion of economy could be encourage only with increasing of governmental spending. Fiscal discipline could enable collars of economies of European Governments.

Against economic difficulties with which EU is facing, question for expanding is still open on the agenda of the members of the Union. Europeanization of the Balkans, the Union solves with concrete political decisions- candidate status of Serbia, high pre-accessible agreement with R. of Macedonia and with receipt of 28th member in great European family, Republic of Croatia, which after the successful referendum in the beginning of this year, expects the official admission in June 2013. All this could be understood as an act of politicization of the Union, against the crises in its foreign politics and security, crises of European identity expressed as European citizenship and crises in structural reforms of the Union. Credibility of European Union should be proved also through West Balkans, as logical continuity and geographical rounding of formal European space. With this, the Union at least these years will try to balance its internal, external and existential questions for which many international analysts claim to be basis reasons of European crisis and crises of identity of European Union, and it is predicted destruction within a decade. While USA turn the attention from the Balkans because of Middle East Crises and global security questions, the European Union, both as political alliance and natural decision, should finalize the Balkans expanding that has been started. In contrary, it should happen Balkanization of Europe because of inputting of Balkans norms through old and new ladies in Europe, between tradition and new value system of europeanizated countries of South-East Europe in which there are still several countries of West Balkans as a part of South-East Europe.

\section{Notes:}

1) Economist, cited according Dnevnik, 5 April, 2005

2) Financial Times, 8 April 2006

3) New Macedonia, 22 Jan 2012

4) Statements of Gernot Erler for radio Deutsche Welle on 12 April 2009

5) Analyze of Report of international organization located in USA, Human Rites vogue 


\section{References}

[1] European Commision. Communication from the Commision on the Application of State Aid Rules to public Service Broadcastin., Press relas:233- Nr:9755/01, luksemburg,21 June 2001.

[2] Petkovska, Antoanela. The cultural identity - difference in oneself. Skopje: Templum,2003.

[3] Siljanovska, Liljana. The media culture in the Euro integrative processes. Tetovo: Arberia Design,2007.

[4] Baran, J.Stanley. Introduction to mass communication.Mountain View: Myfield Publishing Company.2002.

[5] Gruevski, Tome . Communication and culture, Skopje: Student's word.2004

[6] Kuncih M, Astrid Cipfel , Introduction to publication and communication sciences, Fondation "Fridrix Ebert", Skopje. 1998 